\title{
Fabrication and Study of Power- Output of Multi- Chamber Microbial Fuel Cells (Mfcs) With Clay as Ion Exchange Partition
}

\author{
Reuben Yao Tamakloe, PhD \\ Michael Kweku Edem Donkor, PhD \\ Keshaw Singh, Prof. \\ Department of Physics, College of Science, \\ Kwame Nkrumah University of Science and Technology (KNUST), \\ Kumasi, Ghana
}

Doi: 10.19044/esj.2017.v13n30p173 URL:http://dx.doi.org/10.19044/esj.2017.v13n30p173

\begin{abstract}
The main challenges in the construction of microbial fuel cells (MFCs) are the identification of materials, designs, and architectures that may maximize power generation efficiency and fabrication cost. In view of these facts, an attempt was made to design and fabricate Multi - Chamber MFCs of different configuration using locally available Mfensi clay as ionexchange partitions. The performance of each micro-cell, combined effect of the total system as one cell, and the overall performance were studied. The volume of each chamber of these cells was approximately $130 \mathrm{~cm}^{3}$. It was found that the wastewater of chemical oxygen demand (COD) that was 6340 $\mathrm{gm} / \mathrm{L}$ used in the MFCs yielded a maximum open circuit voltage (OCV) of $1421 \pm 30 \mathrm{mV}$. The peak power density of $33.30 \mathrm{~mW} / \mathrm{cm}^{2}\left(0.037 \mathrm{~mA} / \mathrm{cm}^{2}\right)$ at $1000 \Omega$ was normalized to the anode surface area.
\end{abstract}

Keywords: Multi-chamber, Mfensi clay, ion-exchange partition, COD

\section{Introduction}

The energy demand in the world keeps growing every year, as there is a continuous step up in gadget acquisition. In the world today, most researches in the energy sector are more focused on fuel cells fabrication due to inadequacy of fossil fuel resources. As a result, there is an urgent need to develop a holistic energy platform that produces sufficient energy while at the same time reduces $\mathrm{CO}_{2}$ emissions to meet 2050 energy needs on a carbon neutral basis (Logan, 2008). The main challenge in constructing a microbial fuel cell (MFC) as stated by Logan is first in identifying materials and architectures that maximize power generation and Coulombic efficiency, and 
that also minimize cost. Through an understanding of the MFC system, it will be probable to improve the properties and design of a cell for maximum efficiency. Veeranjaneya et al. (2010) have explained the following four primary mechanisms proposed for microorganisms to transfer electrons to electrodes: (1) Indirect electron transport by reduced products; (2) Electron transport by artificial mediators; (3) Electron transport through microorganism's own mediator; (4) Direct electron transfer. However, MFC and its derived technologies have been used for many applications, including waste disposal, remote power supplies, water treatments, chemicals production, and biosensor (Calder, 2007).

Consequently, quite a number of researchers have reported that the anode materials used in MFCs are to be highly conductive, non-corrosive, high specific surface area, high porosity, non-fouling, inexpensive, electrically conductive, and should be easily made and scaled to larger sizes (Logan, 2008). Samsudeen et al. (2015) studied multi-chamber microbial fuel cell which consists of four anodes and a cathode component separated by a membrane. They achieved a maximum open circuit voltage (OCV) of $720 \mathrm{mV}$ and the peak power density of $52.8 \mathrm{~mW} / \mathrm{m}^{2}\left(162.5 \mathrm{~mA} / \mathrm{m}^{2}\right)$ at $100 \Omega$ as normalized to the anode surface area. Aelterman et al. (2006) investigated the performance of six cells stacked in parallel and series that had a significant increase on the voltages $\left(2.02 \mathrm{~V}\right.$ at $\left.228 \mathrm{~W} \mathrm{~m}^{-3}\right)$ and the currents (255 $\mathrm{mA}$ at $248 \mathrm{~W} \mathrm{~m}^{-3}$ ), while retaining high power outputs.

In the current investigation, an attempt was made to generate electricity from MFC by utilizing multiple chambers connected by Mfensi clay as ion-exchange partitions. The following objectives were considered:

- $\quad$ To measure the performance of each micro-cell;

- $\quad$ To observe the multiple effect on each micro-cell on the bulk system;

- $\quad$ To observe the combined effect of the total system as one cell; and

- $\quad$ To observe the total performance.

\section{Materials and methods}

\section{Fabrication of MFCs Chambers}

The clay material was obtained from Mfensi, a town near Kumasi Ghana. Table 1 shows the constituent of the clay as used in earth wares sold in the Ghanaian market.

Table 1. Composition of Mfensi Clay from Geological Survey Department (Ghana) X-Ray Fluorescence Laboratory Results

\begin{tabular}{|c|c|c|c|}
\hline Element & $\%$ & Element & $\%$ \\
\hline $\mathrm{Na}_{2} \mathrm{O}$ & 6.15 & $\mathrm{~K}_{2} \mathrm{O}$ & 1.66 \\
\hline $\mathrm{MgO}$ & 1.28 & $\mathrm{CaO}$ & 0.54 \\
\hline $\mathrm{Al}_{2} \mathrm{O}_{3}$ & 13.82 & $\mathrm{TiO}_{2}$ & 0.04 \\
\hline $\mathrm{SiO}_{2}$ & 65.26 & $\mathrm{MnO}$ & 0.07 \\
\hline
\end{tabular}




\begin{tabular}{|c|c|c|c|}
\hline $\mathrm{P}_{2} \mathrm{O}_{5}$ & 0.23 & $\mathrm{FeO}_{3}$ & 0.83 \\
\hline $\mathrm{SO}_{3}$ & 0.10 & LOI & 10.00 \\
\hline $\mathrm{Cl}$ & 0.02 & Total & 100 \\
\hline
\end{tabular}

The varying chambers were molded and fired at the Department of Ceramics, KNUST. The chambers were in 2, 4, 6, and 9 sets. As shown in Figure 1, each chamber is $3.8 \mathrm{~cm} \mathrm{x} 3.8 \mathrm{~cm} \mathrm{x} 9 \mathrm{~cm}$ (approx. $130 \mathrm{~cm}^{3}$ in volume) and $0.6 \mathrm{~cm}$ thick. Porosity was measured to be $14 \%$. The outer part of each set of the pot was coated to prevent the liquid from seeping out.

\section{Wastewater Used in MFCs}

Wastewater from the Guinness Ghana Brewery Limited (GGBL, Kumasi) has being our favorite for anode substrate. This is primarily because of its known source and safety measures attached to its disposal. Besides, it is suitable for electricity generation in MFCs due to the food-derived nature of the organic matter (Pant et al., 2010; Pant et al., 2016). Good results were obtained from earlier studies with this wastewater with varying CODs (Tamakloe et al., 2014; Tamakloe et al., 2015). Each cell was fed with wastewater of COD equals to $6340 \mathrm{gm} / \mathrm{L}$ and with $80 \%$ concentration of $\mathrm{H}_{2} \mathrm{O}_{2}$ alternatively. $80 \%$ concentrated $\mathrm{H}_{2} \mathrm{O}_{2}$ was used earlier to ascertain the veracity of suitable dilution for higher performance (Tamakloe, 2015).

\section{Choice of Electrodes}

Most of the publications on suitable electrodes (Wei et al., 2011; Logan, 2008) have laid emphasis on carbon and its variance. Nevertheless, these experiments continually use zinc rods and copper plates, as electrodes, for good results. In the present work, zinc plates with surface area of $24 \mathrm{~cm}^{2}$ each were placed in the wastewater. Also, copper rod of same surface area was placed in the $\mathrm{H}_{2} \mathrm{O}_{2}$ respectively, making each adjacent pot to form a cell.

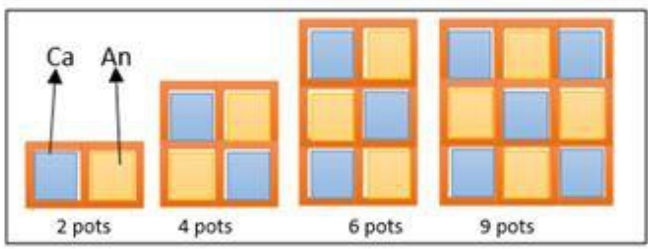

$\mathrm{Ca}=$ Cathode $(\mathrm{Cu})$

$\mathrm{An}=$ Anode $(\mathrm{Zn})$

Figure 1. Designed and fabricated Mfensi clay chambers; anode/cathode applied to all cells

\section{Measurements}

Each cell was connected to Datalogger (Campbell Sci CR10X). Open circuit voltage $(\mathrm{OCV})$ and potential drop across $1 \mathrm{~K}$ load were recorded per minute for 35 days. Ambient temperature was varied over the period between $24{ }^{\circ} \mathrm{C}$ and $25^{\circ} \mathrm{C}$. 


\section{Parallel Connection}

4, 6, and 9 combinations were connected in parallel (Figure 2a) and to the Datalogger. That is, zinc plates in each anode pot were connected together and copper plates were also connected together as one terminal.

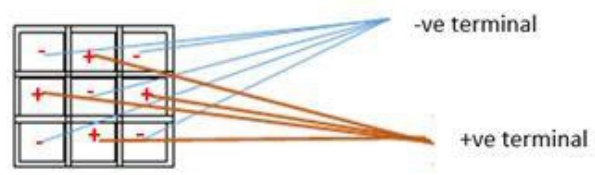

Figure 2a. Parallel cell configuration ( 9 chambered cell)

\section{Series Connection}

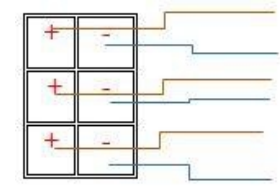

Figure 2b. Series cell configuration

Series connection in the multi system appeared isolated as shown in Figure $2 \mathrm{~b}$. Also, each cell was connected to a load and thus in turn worked independently. However, such single cell measurement was plotted as shown in Figure 3 and 4.

\section{Results and discussion}

There were two aspects that these experiments sought to compare; 1) measure the performance of a single cell in the multi MFC system;2) performance of total multi cell as a single cell. Although all the cells were co-joint with each other as the partition between them act as an ion-exchange medium. Each adjacent pot combination in the alternative forms a cell. The cells were also taken through the polarization measurements using resistors of $100 \Omega$ to $15000 \Omega$. Voltage drops were recorded through PeakTech 2010DMM Multimeter. 


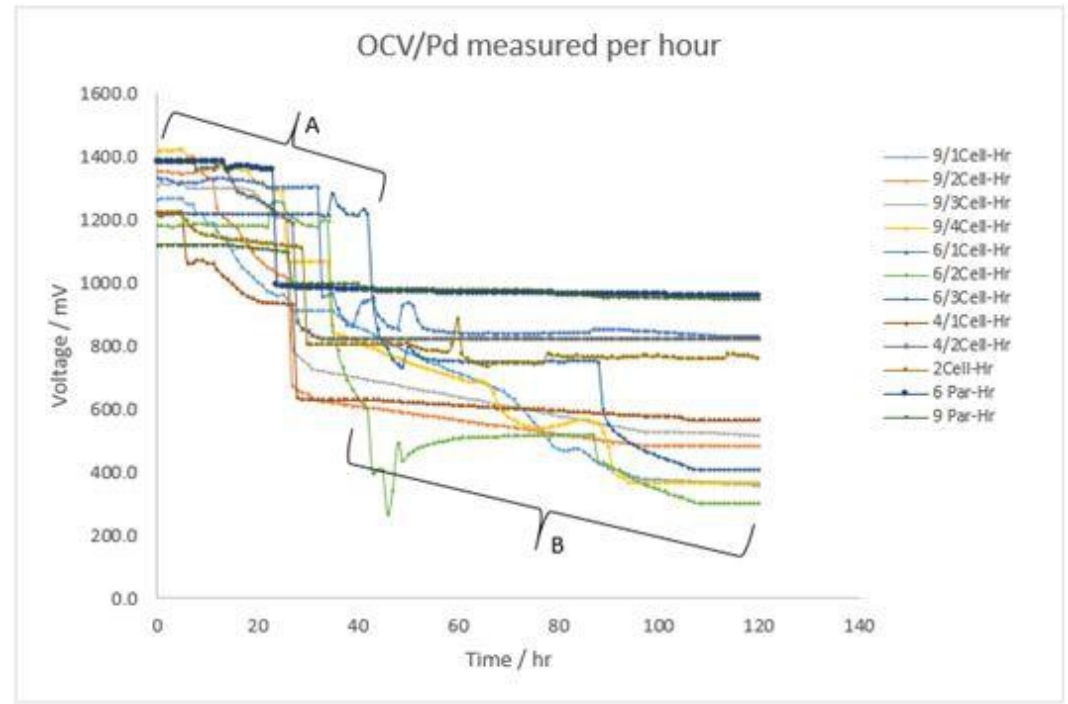

Figure 3. Voltage recorded for the first 5 days

The first portion of Figure 3 (A) on the curves represented OCVs recorded by the Datalogger without load. When the loads were connected, there were sharp drops in line with ohm's law of electric circuit calculation (Folivi et al., 1977). Some of the cells continually dip with hours of operation, while others maintain constant voltages (B). 9 and 6 chambered cells were configured into parallel cells each respectively. However, these were the top 2 of higher operation voltages, meaning these can be used for longer operation period.

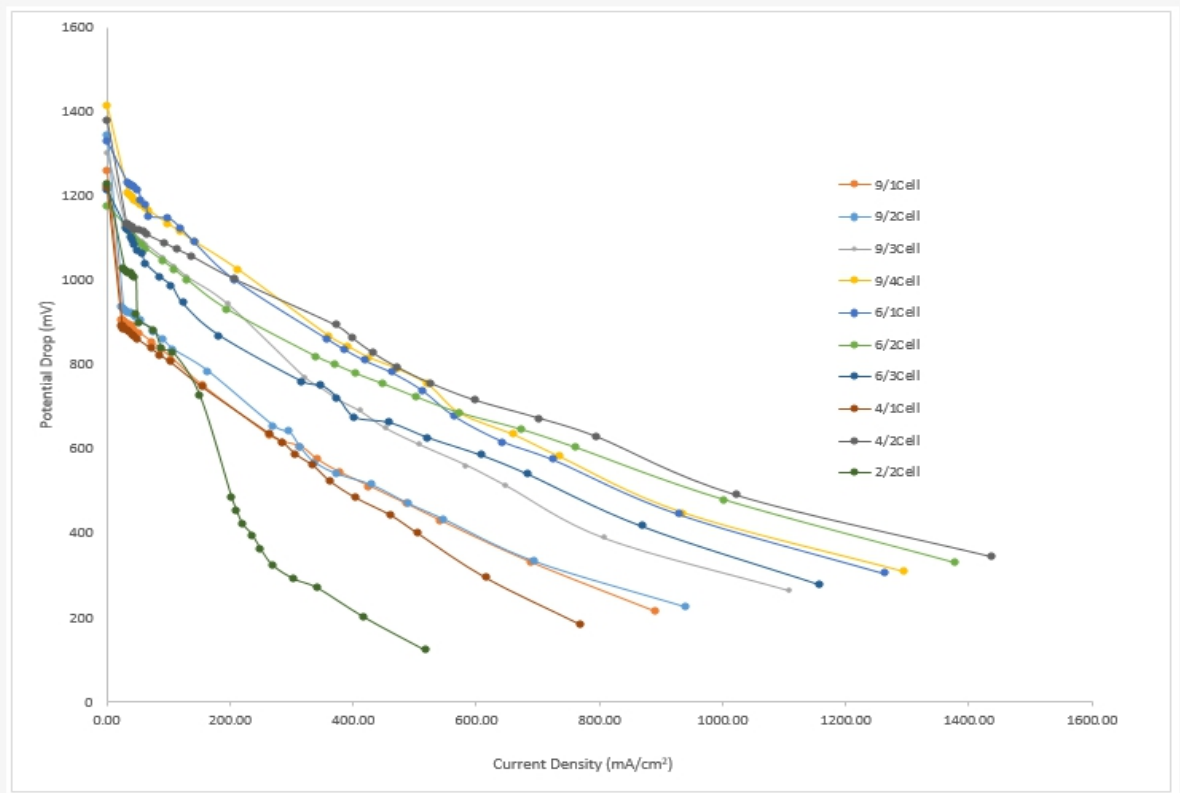

Figure 4. Voltage drop across varying resistors against current density 
Current density was calculated based on the surface area of the anode electrode $\left(I_{D}=P d / R A_{a n}\right)$, and Power density was then calculated using $P=$ $I_{D} E$ (where $\mathrm{I}_{\mathrm{D}}$ is the current density and $E$ the voltage drop).

It was observed that OCV did not follow a pattern (Figure 4). The fourth cell from the 9 chambered cell had the highest OCV of $1414 \mathrm{mV}$ which was probably due to the fact that this particular cell had two anodes and one cathode.

Table 2. Comparison of individual cells in the multi MFC system

\begin{tabular}{|c|c|c|c|c|c|c|}
\hline & $\begin{array}{c}\mathrm{OCV} / \\
\mathrm{mV}\end{array}$ & Resistance $/ \Omega$ & $\begin{array}{c}\mathrm{Pd}: \\
\mathrm{E} / \mathrm{mV}\end{array}$ & Current/mA & $\begin{array}{c}\text { Current } \\
\text { Density } / \mathrm{mA} / \mathrm{cm}^{2} \\
\end{array}$ & $\begin{array}{c}\text { Power } \\
\text { Density } / \mathrm{mW} / \mathrm{cm}^{2} \\
\end{array}$ \\
\hline \multirow{4}{*}{$\begin{array}{c}9 \\
\text { Chambered } \\
\text { cells }\end{array}$} & 1260 & 1000 & 633 & 0.633 & 0.0264 & 16.6954 \\
\hline & 1347 & 1000 & 654 & 0.654 & 0.0273 & 17.8215 \\
\hline & 1302 & 1000 & 771 & 0.771 & 0.0321 & 24.7684 \\
\hline & 1414 & 1000 & 868 & 0.868 & 0.0362 & 31.3927 \\
\hline \multirow{3}{*}{$\begin{array}{c}6 \\
\text { Chambered } \\
\text { Cell }\end{array}$} & 1331 & 1000 & 861 & 0.861 & 0.0359 & 30.8884 \\
\hline & 1179 & 1000 & 819 & 0.819 & 0.0341 & 27.9484 \\
\hline & 1215 & 1000 & 761 & 0.761 & 0.0317 & 24.1300 \\
\hline \multirow{2}{*}{$\begin{array}{c}4 \\
\text { Chambered } \\
\text { Cell } \\
\end{array}$} & 1223 & 1000 & 637 & 0.637 & 0.0265 & 16.9070 \\
\hline & 1380 & 1000 & 894 & 0.894 & 0.0373 & 33.3015 \\
\hline $\begin{array}{c}2 \\
\text { Chambered } \\
\text { (one cell) }\end{array}$ & 1228 & 1000 & 486 & 0.486 & 0.0203 & 9.8415 \\
\hline $\begin{array}{l}9 \text { Parallel(as } \\
\text { one cell) }\end{array}$ & 1118 & 1000 & 903 & 0.903 & 0.0125 & 11.3251 \\
\hline $\begin{array}{c}6 \text { Parallel(as } \\
\text { one cell) }\end{array}$ & 1380 & 1000 & 994 & 0.994 & 0.0138 & 13.7227 \\
\hline $\begin{array}{c}4 \text { Parallel(as } \\
\text { one cell) }\end{array}$ & 1223 & 1000 & 835 & 0.835 & 0.0174 & 14.5255 \\
\hline
\end{tabular}

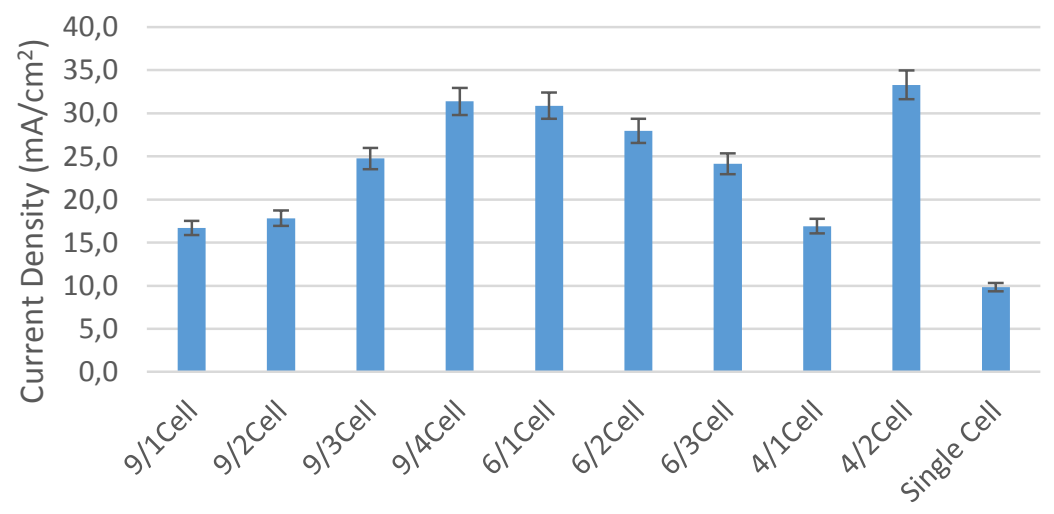

Cell Type

Figure 5. Histogram showing the comparison of individual cells in the multi MFC system 
Both polarization and power curves for $4 / 2$ Cell show the highest yield compared to 4/1Cell. Although the OCV for 9/4Cell was the highest, it was not consistent with ohmic portion of characteristic curves of Figure 4 and 6. These curves show how well the cells maintain voltages as a function of the current produced. Resistive effects in fuel cells reduce the efficiency of the cell by dispelling power in the partitions and substrate resistances. This effect is also observed due to the insulation of the anode electrode. The voltage generated here is far more complicated to understand or predict. As usual, the inference can be deduced from the total result. Almost all the individual cells have their internal resistance $R_{\text {int }}=330 \Omega$ (Logan, 2008). Therefore, we see that maximum power occured at a point where $R_{\text {int }}=R_{\text {ext }}$, then $P_{\max }=E_{\text {emf }} / 4 R_{\text {int }}$.

The parameter that must have caused the variation based on nature of the histogram in Figure 5 with regard to 4/2Cell might be due to the partition characteristic between anode/cathode of the cell with all other factors been the same; i.e. substrates, anode, cathode, and ambient conditions.

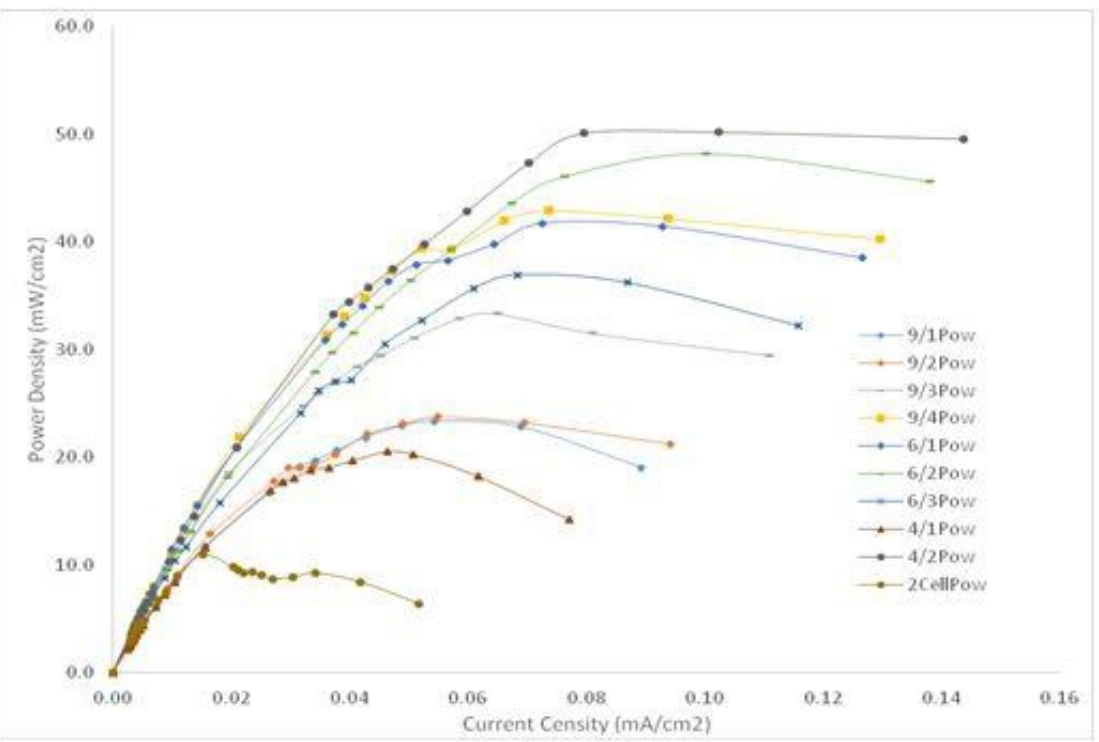

Figure 6. Power density verse current density comparing individual cell in multi MFC system 


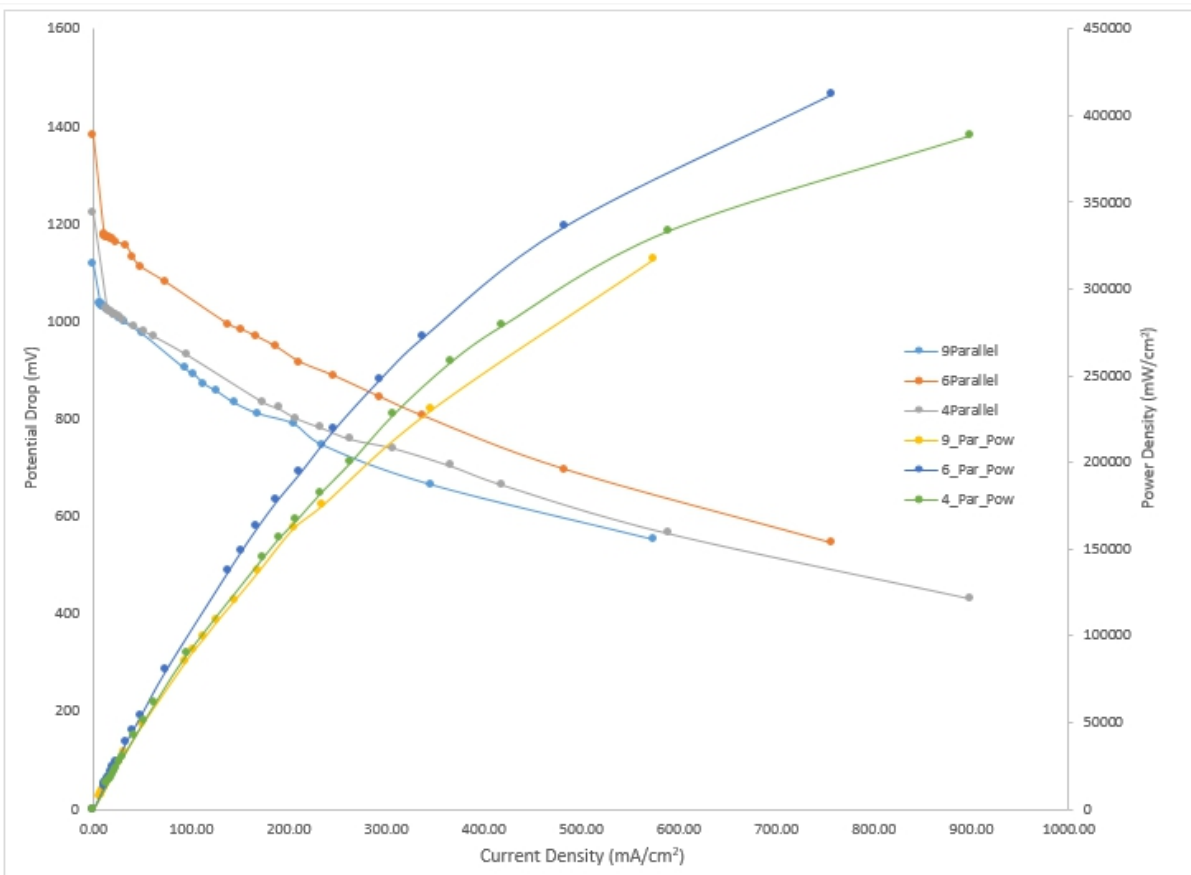

Figure 7. Polarization and power density curves for parallel combination multi MFC system

The maximum power as shown in Figure 7 was $41.25 \mathrm{~mW} / \mathrm{cm}^{2}$ for 9 chambered cells. The activation losses and ohmic portions of the polarization curves were more pronounced in both Figure 4 and 7. The concentration polarization drops were overcome within the range of load/resistors (100 $15000 \Omega$ ) used for the measurements. Concentration losses are the most important loss parameters to be overcome for optimum design of the MFC architecture. These losses were said to arise from the resistance of ion conduction due to the substrates and the membrane or partition between anode and cathode, and the flow of electrons through the electrodes to the contact load points (Logan, 2008). Our choice of clay partition could have accounted for reduction in concentration losses. It also ensures good contacts in the circuit and the source of anode substrate that enhanced solution conductivity.

\section{Conclusion}

This experiment verified the performance of multi-chambered MFCs. Performance of each micro cell in the system was observed to be significant in terms of their yields as could be in standalone single cell. Each adjacent cell tends to supplement the other so that series configuration is not possible in the same multi-system. In parallel configuration, all anode terminals are connected as one and all cathode terminals are connected together, resulting in higher current as shown in Figure 7. This higher power can therefore 
perform for longer period when connected to a load. Few experimental uses, as in connection to digital watches, attested to such performances.

Furthermore, there is a coordination efforts of different scientific fields like electrochemists and materials scientists to delve into effects of the Mfensi clay in the development of several potential practical applications for other electronic systems. Even if it is certain that the production of high levels of electricity from MFC is far from target, an understanding of the coupling of clay material to enhance electron transfer to electrodes is probable to yield significant insights into the diversity of microbial respiratory abilities. In addition, it might lead to future applications in microelectronics.

\section{Acknowledgements}

The authors sincerely acknowledge the management of Guinness Ghana Breweries Limited (GGBL, Kumasi) and staffs for the supply of wastewater and their help with the analytical measurements of COD for the entire project.

\section{References:}

1. Aelterman, P., Rabaey, K., Pham, H. T., Boon, N., and Verstraete, W. (2006). Continuous Electricity Generation at High Voltages and Currents Using Stacked Microbial Fuel Cells Environ. Sci. Technol. 40(10), 3388-3394.

2. Bruce E. Logan (2008). Microbial Fuel Cells. The Pennsylvania State University. WILEY-INTERSCIENCE, A John Wiley \& Sons, Inc., Publication pp 3-62.

3. Calder, M. A. (2007). Modeling of a Microbial Fuel Cell Norwegian University of Science and Technology Department of Energy and Process Engineering

4. Folivi, L. E., Godman, A. (1977). New Certificate Physics. Pub: Longman Group Ltd., pp 310 - 314.

5. Pant, D., et al. (2010). A review of the substrates used in microbial fuel cells (MFCs) for sustainable energy production. Bioresour. Technol. doi:10.1016/j.biortech.2009.10.017.

6. Pant, D., et al. (2016). Evaluation of Bioelectrogenic Potential of Four Industrial Effluent as Substrate for Low Cost Microbial Fuel Cells Operation Environmental Engineering and Management Journal, August 2016, Vol.15, No. 8, 1897-1904

7. Samsudeen, N., Sharma, A., Radhakrishnan, T. K., and Manickam Matheswarana (2015).Performance investigation of multi-chamber microbial fuel cell: An alternative approach for scale up system. 
Journal of Renewable and Sustainable Energy 7(4) · July 2015 AIP Publishing LLC. [http://dx.doi.org/10.1063/1.4923393].

8. Veeranjaneya, L. R., S., Pradeep, S. K and Young-Jung, W. (2010). Microbial Fuel Cells (MFCs) - a novel source of energy for new millennium Current Research, Technology and Education Topics in Applied Microbiology and Biotechnoly. A. Mendez-Vilas (Ed.).

9. Tamakloe, R. Y. (2015). Effect of $\mathrm{COD}$ and $\mathrm{H}_{2} \mathrm{O}_{2}$ concentration on DC-MFC. Available online 9 May 2015-Elsevier http://dx.doi.org/10.1016/j.renene.2015.04.046 ).

10. Tamakloe, R. Y., Agamasu, H., Singh K. (2014). International Journal of Advanced Research in Engineering and Technology (IJARET), ISSN 0976 - 6480(Print), ISSN 0976 - 6499(Online) Volume 5, Issue 7, July (2014), pp. 30-38 C IAEME

11. Tamakloe, R. Y., Opoku-Donkor, T., Donkor, M., Agamasu, H. (2015). Comparative Study of Double Chamber Microbial Fuel Cells (Dc-Mfcs) Using Mfensi Clay as Ion-Exchange-Partition: Effect of Pot Size. International Journal of Technical Research and Applications e-ISSN: 2320-8163, www.ijtra.com Volume 3, Issue 2 (Mar-Apr 2015), PP. 126-128

12. Wei J., Liang P., Huang X., (2011). Recent progress in electrodes for microbial fuel cells, Bioresource Technology 102 (2011) 9335-9344. www.elsevier.com/locate/biortech. 